\title{
Fecal Calprotectin in Preterm Infants Sepsis with and without Necrotizing Enterocolitis Symptoms
}

\author{
Yani Dewi Suryani, ${ }^{1}$ Dwi Prasetyo, ${ }^{2}$ Dany Hilmanto ${ }^{2}$ \\ ${ }^{1}$ Department of Child Health, Faculty of Medicine, Universitas Islam Bandung, Bandung, Indonesia, \\ ${ }^{2}$ Department of Child Health, Faculty of Medicine, Universitas Padjadjaran, Bandung, Indonesia
}

\begin{abstract}
Necrotizing enterocolitis (NEC) is one of the severe gastrointestinal disorder that predominantly affects preterm infants with high morbidity and mortality. The initial clinical manifestations of NEC are non-specific and indistinguishable from sepsis which making delay in diagnosis. Delayed diagnosis might require surgery and even cause death. Calprotectin is a calcium-binding protein, abundantly present in cytosol fraction of neutrophils, also found in feces, and has been found to increase significantly in gastrointestinal inflammation. This study purpose to compare fecal calprotectin in sepsis preterm infants with symptoms of NEC to sepsis preterm infants without symptoms of NEC. The study was a comparative cross-sectional analytic study performed at the Neonatology ward of Dr. Hasan Sadikin General Hospital Bandung, from October 2013 to January 2014 on 40 sepsis preterm infants aged $<28$ days. Fecal calprotectin was analyzed using enzyme-linked immunoassay (ELISA) kit. MannWhitney U test was used to compare the difference of fecal calprotectin concentration in both groups. There were 20 sepsis preterm infants with symptoms of NEC compared to 20 sepsis infants without abdominal symptoms. The concentration of fecal calprotectin was significantly higher in preterm sepsis infants with symptoms of NEC $(790.67 \mu \mathrm{g} / \mathrm{g})$ than preterm sepsis infants without symptoms of NEC $(247.93 \mu \mathrm{g} / \mathrm{g}, \mathrm{p}=0.019)$. The increasing of fecal calprotectin might provide relevant clinical information to pediatricians for early warning signs of NEC in preterm sepsis infants. In conclusion, fecal calprotectin in preterm sepsis infants with symptoms of NEC is higher compared to those without abdominal symptoms.
\end{abstract}

Key words: Fecal calprotectin, NEC, necrotizing enterocolitis, neonatal sepsis

\section{Calprotectin Feses pada Bayi Kurang Bulan Sepsis dengan dan tanpa Gejala Enterokolitis Nekrotikans}

\begin{abstract}
Abstrak
Enterokolitis nekrotikans (EKN) merupakan salah satu gangguan gastrointestinal yang serius terutama pada bayi kurang bulan dengan angka kesakitan dan kematian yang tinggi. Gejala klinis awal EKN yang tidak spesifik dan sulit dibedakan dengan sepsis menyebabkan keterlambatan diagnosis. Keterlambatan diagnosis dapat menyebabkan diperlukan tindakan pembedahan bahkan kematian. Calprotectin merupakan protein yang berikatan dengan kalsium banyak terdapat dalam sitosol neutrofil, dapat ditemukan dalam feses, dan diketahui meningkat signifikan pada keadaan inflamasi gastrointestinal. Penelitian ini bertujuan membandingkan kadar calprotectin feses pada bayi kurang bulan (BKB) sepsis dengan BKB sepsis tanpa gejala EKN. Penelitian ini merupakan penelitian observasional analitik dengan rancangan kasus kontrol yang dilakukan di ruang rawat Neonatologi RSUP Dr. Hasan Sadikin Bandung dari Oktober 2013 sampai Januari 2014 terhadap 40 BKB sepsis berusia <28 hari. Kadar calprotectin feses dianalisis menggunakan kit enzim-linked immunoassay (ELISA). Analisis data menggunakan Mann-Whitney $U$ test untuk membandingkan kadar calprotectin feses antara kedua kelompok. Terdapat 20 BKB sepsis dengan gejala EKN yang dibanding dengan $20 \mathrm{BKB}$ sepsis tanpa gejala EKN. Konsentrasi calprotectin feses pada kelompok BKB sepsis dengan gejala EKN lebih tinggi $(790,67 \mu \mathrm{g} / \mathrm{g})$ secara bermakna dibanding dengan kelompok BKB sepsis tanpa EKN (247,93 $\mu \mathrm{g} / \mathrm{g}, \mathrm{p}=0,019)$. Peningkatan kadar calprotectin pada feses dapat memberikan informasi klinis bagi dokter sebagai tanda awal EKN pada BKB sepsis. Simpulan, kadar calprotectin feses pada BKB sepsis dengan gejala EKN lebih tinggi dibanding dengan BKB sepsis tanpa gejala EKN.
\end{abstract}

Kata kunci: Calprotectin feses, EKN, enterokolitis nekrotikans, sepsis neonatorum 


\section{Introduction}

Necrotizing enterocolitis (NEC) is one of the most common and devastating diseases in neonates, typically manifests with feeding intolerance, abdominal distention, and bloody stools. It predominantly affects preterm infants with the incidence of about $7 \%$ among very low birth weight (VLBW) infants with high mortality (20-30\%). ${ }^{1}$ The incidence of NEC continues to rise because recent advanced in neonatal medicine have resulted in the survival of preterm infants. Early clinicalmanifestations of NECarenon-specificand difficult to distinguish from other gastrointestinal disorders and neonatal sepsis which can present themselves which similar clinical features to "classical" NEC such as abdominal symptoms. ${ }^{2}$ Diagnosis further hampered by limited diagnostic accuracy of laboratory tests and currently use imaging modalities. ${ }^{3}$ The histopathology of NEC characterized by defects in the intestinal epithelial barrier and gut wall inflammation, while neutrophils are essential in this process. ${ }^{4}$

Calprotectin is calcium and zinc-binding protein found predominantly in neutrophils and macrophages that constitutes about 30$60 \%$ of soluble cytosol proteins in neutrophils. ${ }^{5}$ Significantly increased level of fecal calprotectin (f-calprotectin) seen in a small group of infants with proven NEC. ${ }^{2}$ However, the usefulness of this marker remains controversial in the neonatal period due to high levels in this age range. ${ }^{6}$ The previous study showed that f-calprotectin increased in proven NEC, but not useful in early NEC. ${ }^{2,7,8}$ This study aimed to compare the f-calprotectin level in sepsis preterm infants with symptoms of NEC to sepsis preterm infants without symptoms of NEC.

\section{Methods}

The study was a comparative cross-sectional analytic study in the Neonatology ward of Dr. Hasan Sadikin General Hospital Bandung, West Java, from October 2013 to January 2014. Preterm infants $<37$ weeks aged $<28$ days with sepsis included in this study.

Symptoms of NEC define as abdominal symptoms such as abdominal distension of more than $2 \mathrm{~cm}$, the gastric residue of more than $30 \%$ of feeding, and occasion of blood in stools. Preterm sepsis infant with symptoms of NEC was enrolled consecutively and compared to those preterm sepsis infants without symptoms of NEC.
Infants with severe congenital gastrointestinal malformation and those without defecation in 5 days after enrollment excluded. Sepsis diagnosed based on fetal inflammatory response syndrome (FIRS). Demography, clinical and laboratory data recorded in all patients. Fecal occult blood (FOW) and radiology imaging were done to confirm the diagnosis and determine the staging of NEC. Laboratory test currently in used as classic systemic inflammatory markers in the early suspect NEC are white blood cell (WBC), platelet counts, and C-reactive protein (CRP), were measured from blood sample upon suspicion of NEC. Radiology imaging was done in all infants with symptoms of NEC to confirm the diagnosis and determine the staging of NEC. All suspected NEC infants treated with broad-spectrum parenteral antibiotic including anaerobic coverage and gastric decompression for 5-14 days depending on clinical improvement.

Stool samples were collected from the diapers and frozen at $-80^{\circ} \mathrm{C}$ until analyzing. The stool samples collected just after the time of abdominal symptoms appeared or for those who could not defecate at the time whenever possible, maximum five days after the antibiotic given. F-calprotectin levels were measured using immunodiagnostic kit enzyme-linked immunoassay (ELISA) for calprotectin in stool according to manufacturer's instructions. F-calprotectin concentration provided in mg per kilogram stool. Statistical analysis performed with SPSS version 17.0 for Windows. All data presented as median and range. Kolmogorov-Smirnov test was used to find out normality distribution. Mann-Whitney U test was used to compare between groups with $\mathrm{p}<0.05$ was considered to be statistically significant.

This study approved by the Health Research Ethics Committee of the Faculty of Medicine of the Universitas Padjadjaran Bandung by ethical approval letter number: 369/UN6.C2.1.2/KEPK/ $\mathrm{PN} / 2013$. The aim, risk, and possible benefits of the study ere explained to the parents, and informed consent obtained from each.

\section{Results}

Forty sepsis preterm infants were enrolled and all infants produced stool within five days of initial assessment with an average day of 1.25 days (range 0-4 days) after enrollment. Twenty sepsis preterm infants with abdominal symptoms of NEC, six infants developed NEC stage 2 (proven by pneumatosis intestinal on X-ray) and 14 
Table 1 Characteristics of Sepsis Infants with NEC Symptoms and without NEC Symptoms

\begin{tabular}{lcc}
\hline \multirow{2}{*}{ Characteristics } & \multicolumn{2}{c}{ Sepsis Infants (n=2o) } \\
\cline { 2 - 3 } & With NEC Symptoms & Without NEC Symptoms \\
\hline Age at sampling time (days) & 13.5 & 12.5 \\
$\quad$ Median & $5-29$ & $3-25$ \\
Range & 11 & 10 \\
Gender & 9 & 10 \\
Male & 1,450 & 1,500 \\
Female & $1,100-2,100$ & $1,100-2,200$ \\
Birth weight (grams) & & \\
Median & & \\
Range &
\end{tabular}

Table 2 Laboratory Characteristics in Each Study Group

\begin{tabular}{lcc}
\hline \multirow{2}{*}{ Laboratory Characteristics } & \multicolumn{2}{c}{ Sepsis Infants (n=20) } \\
\cline { 2 - 3 } & With NEC Symptoms & Without Abdominal Symptoms \\
\hline WBC $\left(10^{3} / \mathrm{mm}^{3}\right)$ & 8.1 & 10.1 \\
$\quad$ Median & $2.7-44$ & $2.6-38$ \\
$\quad$ Range & 31 & 45 \\
Platelet $\left(10^{3} / \mathrm{mm}^{3}\right)$ & $4-295$ & $3-249$ \\
$\quad$ Median & 88.8 & 80.75 \\
$\quad$ Range & $15.4-226$ & $15-398$ \\
C-reactive protein $(\mathrm{mg} / \mathrm{dL})$ & 7 & 3 \\
$\quad$ Median & 13 & 17 \\
$\quad$ Range & & \\
Fecal occult blood & & \\
$\quad$ Positive & & \\
$\quad$ Negative & &
\end{tabular}

defined as NEC stage I (suspected NEC) at final diagnosis, and there was no stage 3 of NEC. There were 11 males and nine females in symptoms of NEC group with median birth weight were less than 1,500 gram. The characteristics of the subject presented in Table 1.

The laboratory test for classic systemic inflammatory markers in the early suspected NEC is WBC, platelet counts and CRP. White blood cells were normal in both groups, platelet was more decreased in infants with symptoms of NEC infants, and C-reactive protein (CRP) were higher in symptoms of NEC infants compared to without symptoms of NEC infants. Fecal occult blood was negative in 7/20 infants with symptoms of NEC and was positive in $3 / 20$ sepsis infants without symptoms of NEC (Table 2).

Age and gestational age were a possible confounding factor that has an association with f-calprotectin concentration. No significant difference observed in postnatal age and gestational age between both groups ( $p>0.05)$ as

Table 3 Factors Associated with Fecal Calprotectin Concentration in Both Groups

\begin{tabular}{lccc}
\hline \multirow{2}{*}{ Variables } & \multicolumn{2}{c}{ Sepsis Infants (n=20) } & \multirow{2}{*}{ p Value } \\
\cline { 2 - 3 } & With NEC Symptoms & Without NEC Symptoms & $0,635^{*}$ \\
\hline Postnatal age (days) & 12 & 12 & $0,143^{*}$ \\
$\quad$ Median & $5-27$ & $2-25$ & \\
$\quad$ Range & 33 & 34 & \\
Gestational age (weeks) & $29-35$ & $31-36$ & \\
$\quad$ Median & & & \\
Range & &
\end{tabular}

"Mann-Whitney U test 
Table 4 Fecal Calprotectin Level in Sepsis Infants with and without NEC Symptoms

\begin{tabular}{|c|c|c|c|}
\hline \multirow{2}{*}{$\begin{array}{l}\text { F-calprotectin } \\
\text { (mg/kgBW) }\end{array}$} & \multicolumn{2}{|c|}{ Sepsis Infants $(n=20)$} & \multirow{2}{*}{$\begin{array}{l}\text { p Value(95\% CI } \\
\text { Differences) }\end{array}$} \\
\hline & $\begin{array}{l}\text { With NEC } \\
\text { Symptoms }\end{array}$ & $\begin{array}{l}\text { Without Abdominal } \\
\text { Symptoms }\end{array}$ & \\
\hline $\begin{array}{l}\text { Median } \\
\text { Range }\end{array}$ & $\begin{array}{c}456.85 \\
36.1-3212\end{array}$ & $\begin{array}{c}188.1 \\
38.60-724.9\end{array}$ & $\begin{array}{c}0.019^{*} \\
(165.044-920.436)\end{array}$ \\
\hline
\end{tabular}

"Mann-Whitney U test

presented in Table 3.

Median concentration of f-calprotectin in infants with symptoms of NEC were significantly higher than those in the reference $(\mathrm{p}=0.019,95 \%$ CI 165.044-920.436) as shown in Table 4.

\section{Discussion}

Early and reliable diagnosis of NEC is crucial to provide adequate treatment. Clinicians usually rely on clinical signs and symptoms to diagnose NEC while laboratory test such as platelet, CRP, WBC, and imaging technique is used to confirm the diagnosis but not specific in the early stage of the disease. Moreover, sepsis infants can present themselves which similar clinical pictures to that of "classic" symptoms of NEC such as abdominal symptoms. ${ }^{2,3}$

This study found a significant elevation of f-calprotectin in a stool sample of sepsis infants with abdominal symptoms of NEC compared to sepsis infants without abdominal symptoms ( $\mathrm{p}=0.019, \quad 95 \%$ CI 165.044-920.436). This result was different with the previous study by Selimoglu et al. ${ }^{8}$ that found f-calprotectin higher in suspect NEC infants without sepsis compared to healthy newborn but could not find a statistical difference, due to high numbers of newborns with an early stage of the disease. Reisinger et al. ${ }^{7}$ found that calprotectin level in neonates with NEC was significantly higher compared with infants with another diagnosis (sensitivity $81 \%$, specificity 79\%). Another study showed that f-calprotectin level was higher among VLBW non-sepsis infants with NEC like symptoms. ${ }^{9,10}$

It was different from the previous study, in this study we found a significant elevation of f-calprotectin due to the different population in inclusion criteria since we used a sepsis population infant with systemic inflammation. Studies showed that serum calprotectin was increased significantly in sepsis infants but could not be found in stool if the mucosal lining was intact. ${ }^{5}$ Our results were suggesting that intestinal inflammation with epithelial cell disruption has occurred in sepsis infants with abdominal symptoms, so neutrophils have migrated into the intestinal lumen and resulting from an increasing level of calprotectin in the stool. Early treatment should be started immediately in sepsis infants with abdominal symptoms to prevent worse outcomes.

Wefound sixinfants with abdominal symptoms of NEC developed stage 2 NEC at final diagnosis with a median f-calprotectin concentration higher than in suspected NEC. It could be another probable reason why f-calprotectin in this study was significantly higher than the previous study.

Calprotectin present in the cytoplasm of neutrophil granulocytes constitutes about 60\% of soluble cytosol proteins. ${ }^{5}$ It has a regulatory function in the inflammatory process as well as antimicrobial activity. In intestinal inflammation, increasing transepithelial migrations of neutrophils reflect the increasing level of calprotectin in the stool. Its measurement in the stool is now recognized as a reliable marker for detection of organic intestinal disease and is used to differentiate inflammatory bowel disease with irritable bowel syndrome. ${ }^{11,12}$ Moussa et al. ${ }^{13}$ found that fecal calprotectin increased significantly in neonates with feeding intolerance.

A few studies before have been performed to investigate the usefulness of f-calprotectin in preterm infants in the early stage of NEC.,10 Studies showed that there was a dynamic change of f-calprotectin in VLBW infants during the first week of life and no correlation between f-calprotectin with maternal and infants factors. ${ }^{9,14}$ In this study we also found no statistical difference of postnatal and gestational age in both group ( $\mathrm{p}>0.05)$.

We observed a wide range of off-calprotectin in all infants $(36.1-3,212 \mathrm{mg} / \mathrm{kgBW}$ vs $38.6-$ $724.9 \mathrm{mg} / \mathrm{kgBW}$ ). This result may be due to other factors that influence the expression of calprotectin in the stool, such as mucosal permeability, the establishment of gut flora, 
mode of feeding, and genetic factors, or may reflect true inter-individual and intra-individual variability in calprotectin excretion as has been reported..$^{6,9,14}$

We found a high level of CRP and decreased level of platelets in suspect NEC and reference sepsis infant as a parameter of classic systemic inflammation, but there was no significant correlation between f-calprotectin and CRP in sepsis reference and sepsis suspected NEC infants. This result suggests that systemic inflammation does not affect fecal calprotectin in the absence of abdominal symptoms.

There were limitations of this study, first, since the calprotectin excretion in the stool is influenced by bacterial as a role of calprotectin in gut inflammation, the establishment of gut flora must also consider. Second, we did not measure f-calprotectin concentration in healthy preterm infants as a control for baseline concentration of f-calprotectin. Further cohort study with a large number of NEC should be done to clarify the role off-calprotectin to predict who will develop NEC in sepsis infants with abdominal symptoms. The increasing of f-calprotectin might provide a useful early warning sign of NEC in sepsis preterm infants with abdominal symptoms.

\section{Conclusion}

Fecal calprotectin in preterm sepsis infants with symptoms of NEC is higher compared to those without symptoms NEC.

\section{Conflict of Interest}

The authors declare no conflict of interests.

\section{References}

1. Neu J, Walker WA. Necrotizing enterocolitis. N Engl J Med. 2011;364(3):255-64.

2. AydemirO,AydemirC, SarikabadayiYU,Emre Canpolat F, Erdeve O, Biyikli Z, et al. Fecal calprotectin levels are increased in infants with necrotizing enterocolitis. J Matern Fetal Neonatal Med. 2012;25(11):2237-41.

3. Thuijls G, Derikx JPM, van Wijck K, Zimmerman LJI, Degraeuwe PL, Mulder TL, et al. Non-invasive markers for early diagnosis and determination of the severity of necrotizing enterocolitis. Ann Surg. 2010;251(6):1174-80.
4. Petrosyan M, Guner YS, Williams M, Grishin A, Ford HR. Current concepts regarding the pathogenesis of necrotizing enterocolitis. Pediatr Surg Int. 2009;25(4):309-18 .

5. Dhas DBB, Bhat BV, Gane DB. Role of calprotectin in infection and inflammation. Curr Pediatr Res. 2012;16(2):83-94.

6. Rougé C, Butel MJ, Piloquet H, Ferraris L, Legrand A, Vodovar M, et al. Fecal calprotectin excretion in preterm infants during the neonatal period. PLoS One. 2010;5(6): e11083.

7. Reisinger KW, Van der Zee DC, Brouwers HAA, Kramer BW, van Heurn LWE, Buurman WA, et al. Noninvasive measurement of fecal calprotectin and serum amyloid a combined with intestinal fatty acid-binding protein in necrotizing enterocolitis. J Pediatr Surg. 2012;47(9):1640-5.

8. Selimoğlu MA, Temel I, Yıldırım Ç, Özyaln F, Aktaş M, Karabiber H. The role of fecal calprotectin and lactoferrin in the diagnosis of necrotizing enterocolitis. Pediatr Crit Care Med. 2012;13(4):452-4.

9. Yang Q, Smith PB, Goldberg RN, Cotten CM. Dynamic change of fecal calprotectin in very low birth weight infants during the first month of life. Neonatology. 2008;94(4):26771.

10. Yoon JM, Park JY, Ko KO, Lim JW, Cheon EJ, Kim HJ. Fecal calprotectin concentration in neonatal necrotizing enterocolitis. Korean J Pediatr. 2014;57(8):351-6.

11. Sidler MA, Leach ST, Day AS. Fecal S10oA12 and fecal calprotectin as noninvasive markers for inflammatory bowel disease in children. Inflamm Bowel Dis. 2008;14(3):359-66.

12. Campeotto F, Baldassarre M, Butel MJ, Viallon V, Nganzali F, Soulaines P, et al. Fecal calprotectin: cutoff values for identifying intestinal distress in preterm infants. J Pediatr Gastroenterol Nutr. 2009;48(4):507-10.

13. Moussa R, Khashana A, Kamel N, Elsharqawy SE. Fecal calprotectin levels in preterm infants with and without feeding intolerance. J Pediatr (Rio J). 2016;92(5):486-92.

14. Zoppelli L, Güttel C, Bittrich HJ, Andrée C, Wirth S, Jenke A. Fecal calprotectin concentrations in premature infants have a lower limit and show postnatal and gestational age dependence. Neonatology. 2012;102(1):68-74. 